\title{
Adapting the VALUE Rubrics to ABET ETAC Outcomes a-k
}

\section{Prof. Elaine M. Cooney, Indiana University Purdue University, Indianapolis}

Elaine Cooney is the Chair of the Department of Engineering Technology and the Program Director for Electrical Engineering Technology at Indiana University Purdue University Indianapolis. She is also a Senior IDEAL Scholar with ABET, which means that she presents assessment workshops with other Senior IDEAL Scholars. 


\section{Adapting the VALUE Rubrics to ABET ETAC Outcomes a-k}

\section{Introduction}

This paper presents suggestions of which VALUE metarubrics commissioned by the American Association of Colleges \& Universities can be of use to assess student outcomes for engineering technology programs. Although many instructors use rubrics for grading, this paper presents rubrics which can be used for program assessment. Rubrics are an effective way to measure students' abilities. According to Spurlin, "Rubrics are sets of criteria or scoring guides that define what is expected of students."1

The VALUE rubrics use the format shown in Figure 1. Criteria are listed down the left column, achievement levels listed across the top, and performance descriptions are supplied for each criterion/level combination.

\begin{tabular}{|c|c|c|c|c|c|}
\hline & & \multicolumn{4}{|c|}{ Achievement Levels } \\
\hline \multirow{5}{*}{ لَّ } & & Capstone & Milestone & Milestone & Benchmark \\
\hline & Criterion 1 & $\begin{array}{l}\text { Performance } \\
\text { description }\end{array}$ & & & \\
\hline & Criterion 2 & & $\begin{array}{l}\text { Performance } \\
\text { description }\end{array}$ & & \\
\hline & $\cdots$ & & & $\begin{array}{l}\text { Performance } \\
\text { description }\end{array}$ & \\
\hline & Criterion 5 & & & & $\begin{array}{l}\text { Performance } \\
\text { description }\end{array}$ \\
\hline
\end{tabular}

Figure 1: VALUE Rubric Format

\section{VALUE Project Background}

The Association of American Colleges and Universities started the VALUE (Valid Assessment of Learning in Undergraduate Education) project in $2007^{2}$. This program was created in order to better show educational benefits, quality of learning, and retention and graduation rates. Since there are no standardized tests for the Essential Learning Outcomes (ELOs), there was a need to develop a way to document and assess student learning in undergraduate education.

The VALUE project was driven by an advisory board made up of 12 people, national and international leaders. The main goal was to generate a way to evaluate student learning that was based on the work students produced through the curriculum across a set of Essential Learning Outcomes (ELOs) that faculty and professionals stated were critically important for student success.

Through this project, VALUE rubrics were created, for higher education, for the purpose of assessing the quality of student learning and achievement. These rubrics were not intended to be used for grading purposes, but for the purpose of collecting evidence of student learning. 
For each completed rubric, a set of the most common criteria or characteristics of learning were identified. Achievement levels were separated into four different levels and performance descriptors for each level of criterion was established for each learning outcome.

The following are the VALUE Rubrics that have been created:

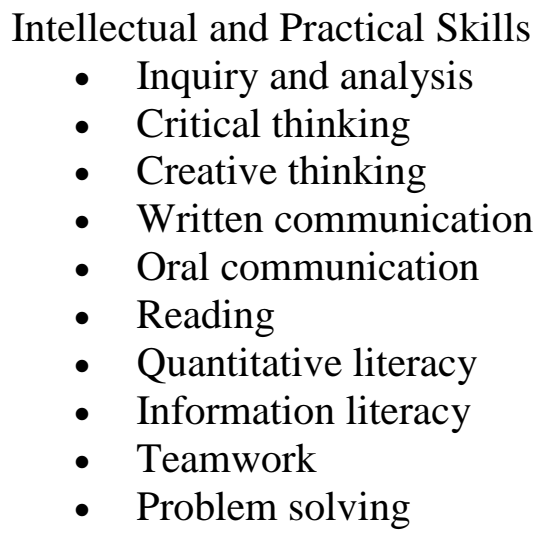

\author{
Personal and Social Responsibility \\ - Civic knowledge and \\ engagement-local and global \\ - Intercultural knowledge and \\ competence \\ - Ethical reasoning \\ - Foundations and skills for \\ lifelong learning \\ - Global Learning \\ Integrative and Applied Learning \\ - Integrative and applied learning
}

The VALUE Rubrics can be found in their entirety on the AAC\&U website:

http://www.aacu.org/value/rubrics. Readers are encouraged to download complete copies of the rubrics. An example of one rubric, “Teamwork," may be found in the appendix of this paper.

\section{ETAC ABET Student Outcomes (a-k)}

In the Criteria for Accrediting Engineering Technology Programs, The Engineering Technology Accreditation Commission of ABET requires each program to have documented student outcomes.

For baccalaureate degree programs, these student outcomes must include, but are not limited to, the following learned capabilities:

a. an ability to select and apply the knowledge, techniques, skills, and modern tools of the discipline to broadly-defined engineering technology activities;

b. an ability to select and apply a knowledge of mathematics, science, engineering, and technology to engineering technology problems that require the application of principles and applied procedures or methodologies;

c. an ability to conduct standard tests and measurements; to conduct, analyze, and interpret experiments; and to apply experimental results to improve processes;

d. an ability to design systems, components, or processes for broadly-defined engineering technology problems appropriate to program educational objectives;

e. an ability to function effectively as a member or leader on a technical team;

f. an ability to identify, analyze, and solve broadly-defined engineering technology problems;

g. an ability to apply written, oral, and graphical communication in both technical and non-technical environments; and an ability to identify and use appropriate technical literature; 
h. an understanding of the need for and an ability to engage in self-directed continuing professional development;

i. an understanding of and a commitment to address professional and ethical responsibilities including a respect for diversity;

j. a knowledge of the impact of engineering technology solutions in a societal and global context; and

k. a commitment to quality, timeliness, and continuous improvement. ${ }^{2}$

The document goes on to explain that the program must assess how well students attain these outcomes.

For the purpose of this study, we have divided the student outcomes into two groups: professional skills and technical skills:

Table 1: Professional vs. Technical Skills

\begin{tabular}{|l|l|}
\hline \multicolumn{1}{|c|}{ Professional Skills } & \multicolumn{1}{c|}{ Technical Skills } \\
\hline e. technical team & a. knowledge ... of the discipline ... \\
\hline $\begin{array}{l}\text { g. communication ... identify and use } \\
\text { appropriate technical literature }\end{array}$ & $\begin{array}{l}\text { b. apply knowledge of mathematics, } \\
\text { science ... to engineering technology } \\
\text { problems }\end{array}$ \\
\hline $\begin{array}{l}\text { h. continuing professional development } \\
\text { c. standard tests and measurements ... } \\
\text { experiments }\end{array}$ \\
\hline $\begin{array}{l}\text { i. professional and ethical responsibilities, } \\
\text { respect for diversity }\end{array}$ & d. design \\
\hline $\begin{array}{l}\text { j. solutions in a societal and global context } \\
\text { k. quality, timeliness, and continuous }\end{array}$ & f. solve problems \\
\hline
\end{tabular}

Table 2 presents a matrix of which VALUE Rubrics can support the ETAC student outcomes. Notice the clusters of like criteria. 
Table 2: VALUE Rubrics Matched to Student Outcomes

\begin{tabular}{|c|c|c|c|c|c|c|c|c|c|c|c|}
\hline & 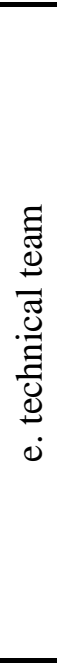 & 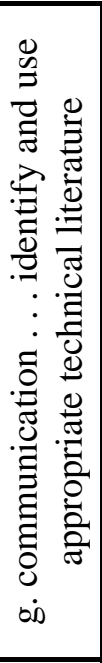 & 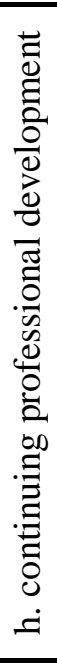 & 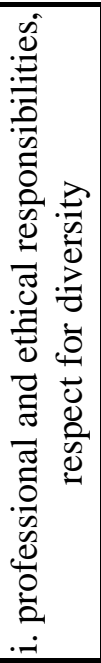 & 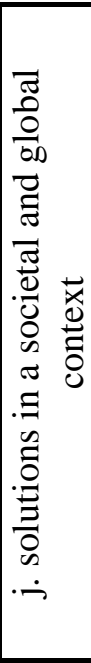 & 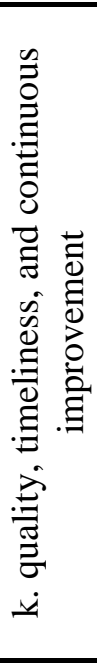 & 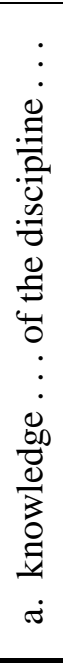 & 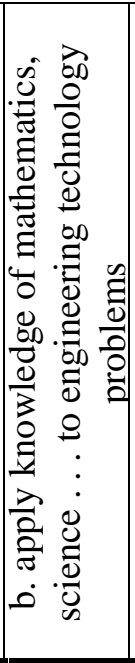 & 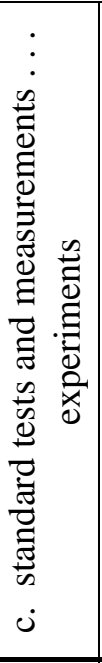 & 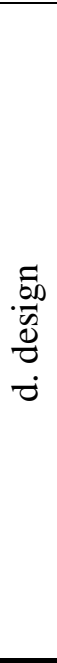 & 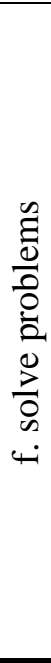 \\
\hline Inquiry and analysis & & & $\mathrm{X}$ & & & $\mathrm{x}$ & $\mathrm{X}$ & & $\mathrm{x}$ & & $\mathrm{X}$ \\
\hline Critical thinking & & & $\mathrm{x}$ & & & $\mathrm{x}$ & $\mathrm{X}$ & & & & \\
\hline Creative thinking & & & & & & & & & & $\mathrm{X}$ & $\mathrm{X}$ \\
\hline Written communication & & $\mathrm{X}$ & & & & & & & & & \\
\hline Oral communication & & $\mathrm{X}$ & & & & & & & & & \\
\hline Reading & & $\mathrm{X}$ & $\mathrm{X}$ & & & & & & & & \\
\hline Quantitative literacy & & $\mathrm{x}$ & & & & $\mathrm{X}$ & & $\mathrm{x}$ & & & $\mathrm{X}$ \\
\hline Information literacy & & $\mathrm{X}$ & $\mathrm{X}$ & & & & & & & & \\
\hline Teamwork & $\mathrm{X}$ & & & & & $\mathrm{X}$ & & & & & \\
\hline Problem solving & & & & & & & & $\mathrm{X}$ & $\mathrm{X}$ & $\mathrm{x}$ & $\mathrm{X}$ \\
\hline $\begin{array}{l}\text { Civic knowledge \& } \\
\text { engagement - local \& } \\
\text { global }\end{array}$ & & & & $\mathrm{X}$ & $\mathrm{X}$ & & & & & & \\
\hline $\begin{array}{l}\text { Intercultural knowledge } \\
\text { and competence }\end{array}$ & $\mathrm{X}$ & & & $\mathrm{X}$ & $\mathrm{x}$ & & & & & & \\
\hline Ethical reasoning & & & & $\mathrm{x}$ & & & & & & & \\
\hline $\begin{array}{l}\text { Foundations and skills } \\
\text { for lifelong learning }\end{array}$ & & & $\mathrm{X}$ & & & & & & & & \\
\hline Global Learning & & & & $\mathrm{X}$ & $\mathrm{x}$ & & & & & & \\
\hline $\begin{array}{l}\text { Integrative and Applied } \\
\text { Learning }\end{array}$ & & & $\mathrm{X}$ & & & & & & & & \\
\hline
\end{tabular}




\section{VALUE Rubrics to Assess ABET Professionalism Skills}

The method used for this study involved three main steps. First, the VALUE rubrics were reviewed and keywords extracted from the criteria and/or performance descriptors. These keywords were then matched to the ABET “a-k" student outcomes. Finally, a list of criteria, gathered from all the relevant VALUE rubrics, was identified for each student outcome. For some outcomes, an entire rubric was identified as applicable; for other outcomes, criteria from multiple rubrics were selected.

Student Outcome e: Technical Team

As expected, the VALUE rubric entitled "Teamwork VALUE Rubric" can be used in its entirety to assess students' abilities to work in a technical team. (See appendix for the complete rubric.) Criteria used by this rubric are:

- Contributes to Team Meetings

- Facilitates the Contributions of Team Members

- Individual Contributions Outside of Team Meetings

- Fosters Constructive Team Climate

- Responds to Conflict

In addition to the teamwork rubric, the "Intercultural Knowledge and Competence VALUE Rubric” has one criterion, Empathy, which can enhance measurement of students' abilities to work in teams.

Table 3: Excerpt from "Intercultural Knowledge and Competence VALUE Rubric"

\begin{tabular}{|l|l|l|l|l|}
\hline & \multicolumn{1}{|c|}{ Capstone } & \multicolumn{2}{c|}{ Milestones } & Benchmark \\
\hline & \multicolumn{1}{|c|}{4} & \multicolumn{1}{|c|}{3} & \multicolumn{1}{c|}{1} \\
\hline $\begin{array}{l}\text { Skills - } \\
\text { Empathy }\end{array}$ & $\begin{array}{l}\text { Interprets } \\
\text { intercultural } \\
\text { experience from the } \\
\text { perspectives of own } \\
\text { and more than one } \\
\text { worldview and } \\
\text { demonstrates ability } \\
\text { to act in a supportive } \\
\text { manner that } \\
\text { recognizes the } \\
\text { feelings of another } \\
\text { cultural group. }\end{array}$ & $\begin{array}{l}\text { Recognizes } \\
\text { intellectual and } \\
\text { emotional dimensions } \\
\text { of more than one } \\
\text { worldview and } \\
\text { sometimes uses more } \\
\text { than one worldview in } \\
\text { interactions. }\end{array}$ & $\begin{array}{l}\text { Identifies } \\
\text { components of other } \\
\text { cultural perspectives } \\
\text { but responds in all } \\
\text { situations with own } \\
\text { worldview. }\end{array}$ & $\begin{array}{l}\text { Views the } \\
\text { experience of } \\
\text { others but does } \\
\text { so through own } \\
\text { cultural } \\
\text { worldview. }\end{array}$ \\
\hline
\end{tabular}

Student Outcome g: Communication \& Use of Technical Literature

There are five complete rubrics which can be used to measure various aspects of this student outcome. The first two, for written and oral communication, are similar to many other rubrics which are in use in engineering technology programs; this is expected because of the "meta- 
rubric" nature of the VALUE rubrics. Lists of the criteria for each are given below; for performance descriptions, please see the complete rubrics.

Written Communication VALUE Rubric Criteria:

- Context of and Purpose for Writing

- Content Development

- Genre and Disciplinary Conventions

- Sources and Evidence

- Control of Syntax and Mechanics
Oral Communication VALUE Rubric Criteria:

- Organization

- Language

- Delivery

- Supporting Material

- Central Message

Both the information literacy and reading rubrics may also be used in their entirety to assess students' abilities to "identify and use appropriate technical literature."

Information Literacy VALUE Rubric Criteria:

- Determine the Extent of Information Needed

- Access the Needed Information

- Evaluate Information and its Sources Critically

- Use Information Effectively to Accomplish a Specific Purpose

- Access and Use Information Ethically and Legally
Reading VALUE Rubric Criteria:

- Genres

- Relationship to Text - Making meanings with texts in their contexts

- Analysis - Interacting with texts in parts and as wholes

- Interpretation - Making sense with texts as blueprints for meaning

- Reader's Voice - Participating in academic discourse about texts

Finally, one criterion from the quantitative reasoning rubric deals with communication which might be especially appropriate for engineering documents.

Table 4: Excerpt from "Quantitative Reasoning VALUE Rubric"

\begin{tabular}{|c|c|c|c|c|}
\hline & \multirow{2}{*}{$\begin{array}{c}\text { Capstone } \\
4 \\
\end{array}$} & \multicolumn{2}{|c|}{ Milestones } & \multirow{2}{*}{$\begin{array}{c}\text { Benchmark } \\
1\end{array}$} \\
\hline & & 3 & 2 & \\
\hline $\begin{array}{l}\text { Communication } \\
\text { Expressing } \\
\text { quantitative } \\
\text { evidence in } \\
\text { support of the } \\
\text { argument or } \\
\text { purpose of the } \\
\text { work (in terms of } \\
\text { what evidence is } \\
\text { used and how it is } \\
\text { formatted, } \\
\text { presented, and } \\
\text { contextualized) }\end{array}$ & $\begin{array}{l}\text { Uses quantitative } \\
\text { information in } \\
\text { connection with } \\
\text { the argument or } \\
\text { purpose of the } \\
\text { work, presents it } \\
\text { in an effective } \\
\text { format, and } \\
\text { explicates it with } \\
\text { consistently high } \\
\text { quality. }\end{array}$ & $\begin{array}{l}\text { Uses quantitative } \\
\text { information in } \\
\text { connection with } \\
\text { the argument or } \\
\text { purpose of the } \\
\text { work, though data } \\
\text { may be presented } \\
\text { in a less than } \\
\text { completely } \\
\text { effective format } \\
\text { or some parts of } \\
\text { the explication } \\
\text { may be uneven. }\end{array}$ & $\begin{array}{l}\text { Uses quantitative } \\
\text { information, but } \\
\text { does not } \\
\text { effectively } \\
\text { connect it to the } \\
\text { argument or } \\
\text { purpose of the } \\
\text { work. }\end{array}$ & $\begin{array}{l}\text { Presents an } \\
\text { argument for which } \\
\text { quantitative } \\
\text { evidence is } \\
\text { pertinent, but does } \\
\text { not provide } \\
\text { adequate explicit } \\
\text { numerical support. } \\
\text { (May use quasi- } \\
\text { quantitative words } \\
\text { such as "many," } \\
\text { "few," "increasing," } \\
\text { "small," and the } \\
\text { like in place of } \\
\text { actual quantities.) }\end{array}$ \\
\hline
\end{tabular}




\section{$\underline{\text { Student Outcome h. Continuing Professional Development }}$}

Assessing lifelong learning is a difficult thing at the undergraduate level. However, educators can assess the skills necessary to engage in lifelong learning using the rubric for "Foundations and skills for lifelong learning." The criteria used in this rubric are listed below; the complete rubric can be found on the AAC\&U website here:

http://www.aacu.org/value/rubrics/LifelongLearning.cfm

Foundations and Skills for Lifelong Learning VALUE Rubric Criteria:

- Curiosity

- Initiative

- Independence

- Transfer

- Reflection

In addition, criteria from five other rubrics can also be used:

Table 6: Additional Criteria to Assess Outcome "h"

\begin{tabular}{|c|c|}
\hline VALUE Rubric & $\begin{array}{l}\text { Criteria to measure "an understanding of the need for and an ability to } \\
\text { engage in self-directed continuing professional development" }\end{array}$ \\
\hline $\begin{array}{l}\text { Inquiry \& } \\
\text { Analysis }\end{array}$ & $\begin{array}{l}\text { - Topic selection } \\
\text { - Existing Knowledge, Research, and/or Views }\end{array}$ \\
\hline Critical Thinking & $\begin{array}{l}\text { - Evidence (Selecting and using information to investigate a point of } \\
\text { view or conclusion) } \\
\text { - Influence of context and assumptions }\end{array}$ \\
\hline Reading & - Comprehension \\
\hline $\begin{array}{l}\text { Information } \\
\text { Literacy }\end{array}$ & - Evaluate Information and its Sources Critically \\
\hline $\begin{array}{l}\text { Integrative and } \\
\text { Applied Learning }\end{array}$ & $\begin{array}{l}\text { - Connections to Experience (Connects relevant experience and } \\
\text { academic knowledge) } \\
\text { - Reflection and Self-Assessment (Demonstrates a developing sense } \\
\text { of self as a learner, building on prior experiences to respond to new } \\
\text { and challenging contexts (may be evident in self-assessment, } \\
\text { reflective, or creative work)) }\end{array}$ \\
\hline
\end{tabular}

An engineering technology program might choose to start with using only the "Foundations and Skills for Lifelong Learning VALUE Rubric" and then add additional criteria if more information is needed to identify student challenges. 


\section{Student Outcome i. Professional and Ethical Responsibilities \& Respect for Diversity}

For the purposes of identifying rubrics for this outcome, it can be divided into two parts: ethics \& diversity. Ethics can be assessed using the "Ethical Reasoning VALUE Rubric" in its entirety. The criteria are:

- Ethical Self-Awareness

- Understanding Different Ethical Perspectives/Concepts

- Ethical Issue Recognition

- Application of Ethical Perspectives/Concepts

- Evaluation of Different Ethical Perspectives/Concepts

In addition, there is one criterion from Information Literacy which may easily apply in many assignments to assess ethics:

Table 7: Excerpt from "Information Literacy VALUE Rubric"

\begin{tabular}{|c|c|c|c|c|}
\hline & Capstone & \multicolumn{2}{|c|}{ Milestones } & Benchmark \\
\hline & 4 & 3 & 2 & 1 \\
\hline $\begin{array}{l}\text { Access and } \\
\text { Use } \\
\text { Information } \\
\text { Ethically } \\
\text { and Legally }\end{array}$ & $\begin{array}{l}\text { Students use correctly } \\
\text { all of the following } \\
\text { information use } \\
\text { strategies (use of } \\
\text { citations and } \\
\text { references; choice of } \\
\text { paraphrasing, } \\
\text { summary, or quoting; } \\
\text { using information in } \\
\text { ways that are true to } \\
\text { original context; } \\
\text { distinguishing } \\
\text { between common } \\
\text { knowledge and ideas } \\
\text { requiring attribution) } \\
\text { and demonstrate a full } \\
\text { understanding of the } \\
\text { ethical and legal } \\
\text { restrictions on the use } \\
\text { of published, } \\
\text { confidential, and/or } \\
\text { proprietary } \\
\text { information. }\end{array}$ & $\begin{array}{l}\text { Students use correctly } \\
\text { three of the following } \\
\text { information use } \\
\text { strategies (use of } \\
\text { citations and } \\
\text { references; choice of } \\
\text { paraphrasing, } \\
\text { summary, or quoting; } \\
\text { using information in } \\
\text { ways that are true to } \\
\text { original context; } \\
\text { distinguishing } \\
\text { between common } \\
\text { knowledge and ideas } \\
\text { requiring attribution) } \\
\text { and demonstrates a } \\
\text { full understanding of } \\
\text { the ethical and legal } \\
\text { restrictions on the use } \\
\text { of published, } \\
\text { confidential, and/or } \\
\text { proprietary } \\
\text { information. }\end{array}$ & $\begin{array}{l}\text { Students use correctly } \\
\text { two of the following } \\
\text { information use } \\
\text { strategies (use of } \\
\text { citations and } \\
\text { references; choice of } \\
\text { paraphrasing, } \\
\text { summary, or quoting; } \\
\text { using information in } \\
\text { ways that are true to } \\
\text { original context; } \\
\text { distinguishing } \\
\text { between common } \\
\text { knowledge and ideas } \\
\text { requiring attribution) } \\
\text { and demonstrates a } \\
\text { full understanding of } \\
\text { the ethical and legal } \\
\text { restrictions on the use } \\
\text { of published, } \\
\text { confidential, and/or } \\
\text { proprietary } \\
\text { information. }\end{array}$ & $\begin{array}{l}\text { Students use correctly } \\
\text { one of the following } \\
\text { information use } \\
\text { strategies (use of } \\
\text { citations and } \\
\text { references; choice of } \\
\text { paraphrasing, } \\
\text { summary, or quoting; } \\
\text { using information in } \\
\text { ways that are true to } \\
\text { original context; } \\
\text { distinguishing } \\
\text { between common } \\
\text { knowledge and ideas } \\
\text { requiring attribution) } \\
\text { and demonstrates a } \\
\text { full understanding of } \\
\text { the ethical and legal } \\
\text { restrictions on the use } \\
\text { of published, } \\
\text { confidential, and/or } \\
\text { proprietary } \\
\text { information. }\end{array}$ \\
\hline
\end{tabular}


"A respect for diversity" can be measured using three other Personal and Social Responsibility VALUE Rubrics: Civic Engagement, Global Learning and Intercultural Knowledge. Table 8 lists these rubrics and the associated criteria.

Table 8: Additional Criteria to Assess Outcome "i": Diversity

\begin{tabular}{|c|c|c|c|c|}
\hline & Capstone & \multicolumn{2}{|c|}{ Milestones } & Benchmark \\
\hline & 4 & 3 & 2 & 1 \\
\hline $\begin{array}{l}\text { Civic } \\
\text { Engagement } \\
\text { Rubric: } \\
\text { Diversity of } \\
\text { Communities } \\
\text { and Cultures }\end{array}$ & $\begin{array}{l}\text { Demonstrates } \\
\text { evidence of } \\
\text { adjustment in own } \\
\text { attitudes and beliefs } \\
\text { because of working } \\
\text { within and learning } \\
\text { from diversity of } \\
\text { communities and } \\
\text { cultures. Promotes } \\
\text { others' engagement } \\
\text { with diversity. }\end{array}$ & $\begin{array}{l}\text { Reflects on how } \\
\text { own attitudes and } \\
\text { beliefs are different } \\
\text { from those of other } \\
\text { cultures and } \\
\text { communities. } \\
\text { Exhibits curiosity } \\
\text { about what can be } \\
\text { learned from } \\
\text { diversity of } \\
\text { communities and } \\
\text { cultures. }\end{array}$ & $\begin{array}{l}\text { Has awareness that } \\
\text { own attitudes and } \\
\text { beliefs are different } \\
\text { from those of other } \\
\text { cultures and } \\
\text { communities. } \\
\text { Exhibits little } \\
\text { curiosity about what } \\
\text { can be learned from } \\
\text { diversity of } \\
\text { communities and } \\
\text { cultures. }\end{array}$ & $\begin{array}{l}\text { Expresses attitudes } \\
\text { and beliefs as an } \\
\text { individual, from a } \\
\text { one-sided view. Is } \\
\text { indifferent or } \\
\text { resistant to what can } \\
\text { be learned from } \\
\text { diversity of } \\
\text { communities and } \\
\text { cultures. }\end{array}$ \\
\hline $\begin{array}{l}\text { Global Learning } \\
\text { Rubric: }\end{array}$ & $\begin{array}{l}\text { Adapts and applies a } \\
\text { deep understanding } \\
\text { of multiple } \\
\text { worldviews, } \\
\text { experiences, and } \\
\text { power structures } \\
\text { while initiating } \\
\text { meaningful } \\
\text { interaction with other } \\
\text { cultures to address } \\
\text { significant global } \\
\text { problems. }\end{array}$ & $\begin{array}{l}\text { Analyzes substantial } \\
\text { connections between } \\
\text { the worldviews, } \\
\text { power structures, } \\
\text { and experiences of } \\
\text { multiple cultures } \\
\text { historically or in } \\
\text { contemporary } \\
\text { contexts, } \\
\text { incorporating } \\
\text { respectful } \\
\text { interactions with } \\
\text { other cultures. }\end{array}$ & $\begin{array}{l}\text { Explains and } \\
\text { connects two or more } \\
\text { cultures historically } \\
\text { or in contemporary } \\
\text { contexts with some } \\
\text { acknowledgement of } \\
\text { power structures, } \\
\text { demonstrating } \\
\text { respectful interaction } \\
\text { with varied cultures } \\
\text { and worldviews. }\end{array}$ & $\begin{array}{l}\text { Describes the } \\
\text { experiences of } \\
\text { others historically or } \\
\text { in contemporary } \\
\text { contexts primarily } \\
\text { through one cultural } \\
\text { perspective, } \\
\text { demonstrating some } \\
\text { openness to varied } \\
\text { cultures and } \\
\text { worldviews. }\end{array}$ \\
\hline $\begin{array}{l}\text { Intercultural } \\
\text { Knowledge } \\
\text { Rubric: } \\
\text { Attitudes - } \\
\text { Openness }\end{array}$ & $\begin{array}{l}\text { Initiates and develops } \\
\text { interactions with } \\
\text { culturally different } \\
\text { others. Suspends } \\
\text { judgment in valuing } \\
\text { her/ his interactions } \\
\text { with culturally } \\
\text { different others. }\end{array}$ & $\begin{array}{l}\text { Begins to initiate } \\
\text { and develop } \\
\text { interactions with } \\
\text { culturally different } \\
\text { others. Begins to } \\
\text { suspend judgment in } \\
\text { valuing her/ his } \\
\text { interactions with } \\
\text { culturally different } \\
\text { others. }\end{array}$ & $\begin{array}{l}\text { Expresses openness } \\
\text { to most, if not all, } \\
\text { interactions with } \\
\text { culturally different } \\
\text { others. Has difficulty } \\
\text { suspending any } \\
\text { judgment in her/ his } \\
\text { interactions with } \\
\text { culturally different } \\
\text { others, and is aware } \\
\text { of own judgment and } \\
\text { expresses a } \\
\text { willingness to } \\
\text { change. }\end{array}$ & $\begin{array}{l}\text { Receptive to } \\
\text { interacting with } \\
\text { culturally different } \\
\text { others. Has } \\
\text { difficulty } \\
\text { suspending any } \\
\text { judgment in her/ his } \\
\text { interactions with } \\
\text { culturally different } \\
\text { others, but is } \\
\text { unaware of own } \\
\text { judgment. }\end{array}$ \\
\hline
\end{tabular}




\section{$\underline{\text { Student Outcome j: Societal and Global Context }}$}

This outcome requires programs to assess student's "knowledge of the impact of engineering technology solutions in a societal and global context." Of all the VALUE rubrics, the Global Learning Rubric most closely matches this outcome, and may be used in its entirety. Criteria are:

- Global Self-Awareness

- Perspective Taking

- Personal and Social Responsibility

- Understanding Global Systems

- Applying Knowledge to Contemporary Global Contexts

In addition, criteria from two other Personal and Social Responsibility Rubrics can add insight to student achievement.

Table 9: Additional Criteria to Assess Outcome "j"

\begin{tabular}{|l|r|}
\hline VALUE Rubric & $\begin{array}{l}\text { Criteria to measure “a knowledge of the impact of engineering technology } \\
\text { solutions in a societal and global context” }\end{array}$ \\
\hline Civic Engagement & $\begin{array}{r}\text { - Analysis of Knowledge } \\
\text { - }\end{array}$ \\
\hline Intercultural & $\begin{array}{l}\text { - Knowledge- Knowledge of cultural worldview frameworks } \\
\text { Knowledge }\end{array}$ \\
\hline
\end{tabular}

$\underline{\text { Student Outcome k. Quality, Timeliness, and Continuous Improvement }}$

For the purpose of this analysis this outcome has been broken into two parts: quality \& continuous improvement and timeliness. The criteria to measure a commitment to continuous improvement come from the techniques of Lean Six-Sigma methodology. These criteria are presented in Table 10.

Table 10: Criteria to Assess Outcome "k": Quality and Continuous Improvement

\begin{tabular}{|c|c|}
\hline VALUE Rubric & $\begin{array}{l}\text { Criteria to measure "a knowledge of the impact of engineering technology } \\
\text { solutions in a societal and global context" }\end{array}$ \\
\hline Inquiry \& Analysis & $\begin{array}{ll}\text { - } & \text { Analysis } \\
\text { - } & \text { Conclusions } \\
\text { - } & \text { Limitations and Implications }\end{array}$ \\
\hline Critical Thinking & $\begin{array}{l}\text { - Conclusions and related outcomes (implications and } \\
\text { consequences) }\end{array}$ \\
\hline $\begin{array}{l}\text { Quantitative } \\
\text { Literacy }\end{array}$ & $\begin{array}{l}\text { - Application / Analysis - Ability to make judgments and draw } \\
\text { appropriate conclusions based on the quantitative analysis of data, } \\
\text { while recognizing the limits of this analysis }\end{array}$ \\
\hline
\end{tabular}


The only VALUE rubric which directly measures timeliness is the Teamwork rubric, which quantifies students' ability to meet a deadline.

Table 11: Excerpt from "Teamwork VALUE Rubric" to assess Timeliness

\begin{tabular}{|c|c|c|c|c|}
\hline & Capstone & \multicolumn{2}{|c|}{ Milestones } & Benchmark \\
\hline & 4 & 3 & 2 & 1 \\
\hline $\begin{array}{l}\text { Individual } \\
\text { Contributions } \\
\text { Outside of } \\
\text { Team Meetings }\end{array}$ & $\begin{array}{l}\text { Completes all assigned tasks } \\
\text { by deadline; work } \\
\text { accomplished is thorough, } \\
\text { comprehensive, and advances } \\
\text { the project. Proactively helps } \\
\text { other team members complete } \\
\text { their assigned tasks to a } \\
\text { similar level of excellence. }\end{array}$ & $\begin{array}{l}\text { Completes all } \\
\text { assigned tasks by } \\
\text { deadline; work } \\
\text { accomplished is } \\
\text { thorough, } \\
\text { comprehensive, } \\
\text { and advances the } \\
\text { project. }\end{array}$ & $\begin{array}{l}\text { Completes all } \\
\text { assigned tasks by } \\
\text { deadline; work } \\
\text { accomplished } \\
\text { advances the } \\
\text { project. }\end{array}$ & $\begin{array}{l}\text { Completes all } \\
\text { assigned tasks } \\
\text { by deadline. }\end{array}$ \\
\hline
\end{tabular}

It might be necessary to revise the performance indicators if most students do not meet the "Benchmark" achievement level.

\section{VALUE Rubrics to Assess ABET Technical Skills}

Engineering technology faculty are less likely to look to VALUE rubrics to assess technical skills, since most of the rubrics were created for use in general education courses. However, there are still applications for the rubrics to measure student achievement of the more technical outcomes.

Student Outcome a: select and apply the knowledge, techniques, skills, and modern tools of the discipline to broadly-defined engineering technology activities

There are two rubrics that can be used for application of outcome a. The first rubric, Critical Thinking VALUE Rubric, has one criterion, Explanation of Issues that can be used to measure the students understanding.

Table 12: Excerpt from "Critical Thinking VALUE Rubric"

\begin{tabular}{|l|l|l|l|l|}
\hline & \multicolumn{1}{|c|}{ Capstone } & \multicolumn{2}{c|}{ Milestones } & \multicolumn{1}{c|}{ Benchmark } \\
\hline & \multicolumn{1}{|c|}{4} & \multicolumn{1}{c|}{3} & \multicolumn{1}{c|}{2} & 1 \\
\hline $\begin{array}{l}\text { Explanatio } \\
\text { n of Issues }\end{array}$ & $\begin{array}{l}\text { Issue/ problem to be } \\
\text { considered critically is } \\
\text { stated clearly and } \\
\text { described } \\
\text { comprehensively, } \\
\text { delivering all relevant } \\
\text { information necessary } \\
\text { for full understanding. }\end{array}$ & $\begin{array}{l}\text { Issue/ problem to be } \\
\text { considered critically } \\
\text { is stated, described, } \\
\text { and clarified so that } \\
\text { understanding is not } \\
\text { seriously impeded by } \\
\text { omissions. }\end{array}$ & $\begin{array}{l}\text { Issue/ problem to be } \\
\text { considered critically is } \\
\text { stated but description } \\
\text { leaves some terms } \\
\text { undefined, ambiguities } \\
\text { unexplored, boundaries } \\
\text { undetermined, and/ or } \\
\text { backgrounds unknown. }\end{array}$ & $\begin{array}{l}\text { Issue/ problem to be } \\
\text { considered critically } \\
\text { is stated without } \\
\text { clarification or } \\
\text { description }\end{array}$ \\
\hline
\end{tabular}

In addition to the Critical Thinking rubric, the Inquiry and Analysis VALUE Rubric includes the entire criterion for outcome a. The list of criteria is given below; for performance descriptions, please see the complete set of rubrics. 
Inquiry and Analysis VALUE Rubric Criteria:

- Topic Selection

- Existing Knowledge, Research, and/or Views

- Design Process

- Analysis

- Conclusions

- Limitations and Implications

Student Outcome b: knowledge of mathematics, science, engineering, and technology to engineering technology problems that require the application of principles and applied procedures or methodologies;

There are two rubrics which can be used to measure various aspects of this student outcome. The first one, Problem Solving, can be used in its entirety. Below are the criteria, for performance descriptions, please view the complete set of rubrics.

Problem Solving VALUE Rubric Criteria:

- Define Problem

- Identify Strategies

- Propose Solutions/Hypotheses

- Evaluate Potential Solutions

- Implement Solution

- Evaluate Outcomes

The second rubric used for outcome $b$ is the Quantitative Literacy VALUE Rubric. There are four criteria in this rubric that can be used to assess a students' knowledge in STEM (Science, Technology, Engineering, and Math) and its problem application. Below are excerpts from the VALUE rubric.

Table 13: Excerpt from "Quantitative Literacy VALUE Rubric"

\begin{tabular}{|c|c|c|c|c|}
\hline & Capstone & \multicolumn{2}{|c|}{ Milestones } & Benchmark \\
\hline & 4 & 3 & 2 & 1 \\
\hline $\begin{array}{l}\text { Interpretation - } \\
\text { Ability to explain } \\
\text { information } \\
\text { presented in } \\
\text { mathematical } \\
\text { forms (e.g., } \\
\text { equations, } \\
\text { graphs, } \\
\text { diagrams, tables, } \\
\text { words) }\end{array}$ & $\begin{array}{l}\text { Provides accurate } \\
\text { explanations of } \\
\text { information presented } \\
\text { in mathematical } \\
\text { forms. Makes } \\
\text { appropriate } \\
\text { inferences based on } \\
\text { that information. For } \\
\text { example, accurately } \\
\text { explains the trend } \\
\text { data shown in a } \\
\text { graph and makes } \\
\text { reasonable } \\
\text { predictions regarding } \\
\text { what the data suggest } \\
\text { about future events. }\end{array}$ & $\begin{array}{l}\text { Provides accurate } \\
\text { explanations of } \\
\text { information presented } \\
\text { in mathematical } \\
\text { forms. For instance, } \\
\text { accurately explains } \\
\text { the trend data shown } \\
\text { in a graph. }\end{array}$ & $\begin{array}{l}\text { Provides somewhat } \\
\text { accurate } \\
\text { explanations of } \\
\text { information } \\
\text { presented in } \\
\text { mathematical } \\
\text { forms, but } \\
\text { occasionally makes } \\
\text { minor errors } \\
\text { related to } \\
\text { computations or } \\
\text { units. For instance, } \\
\text { accurately explains } \\
\text { trend data shown } \\
\text { in a graph, but may } \\
\text { miscalculate the } \\
\text { slope of the trend }\end{array}$ & $\begin{array}{l}\text { Attempts to explain } \\
\text { information presented } \\
\text { in mathematical } \\
\text { forms, but draws } \\
\text { incorrect conclusions } \\
\text { about what the } \\
\text { information means. } \\
\text { For example, } \\
\text { attempts to explain } \\
\text { the trend data shown } \\
\text { in a graph, but will } \\
\text { frequently } \\
\text { misinterpret the } \\
\text { nature of that trend, } \\
\text { perhaps by confusing } \\
\text { positive and negative } \\
\text { trends. }\end{array}$ \\
\hline
\end{tabular}




\begin{tabular}{|c|c|c|c|c|}
\hline & & & line. & \\
\hline $\begin{array}{l}\text { Representation - } \\
\text { Ability to convert } \\
\text { relevant } \\
\text { information into } \\
\text { various } \\
\text { mathematical } \\
\text { forms (e.g., } \\
\text { equations, } \\
\text { graphs, } \\
\text { diagrams, tables, } \\
\text { words) } \\
\end{array}$ & $\begin{array}{l}\text { Skillfully converts } \\
\text { relevant information } \\
\text { into an insightful } \\
\text { mathematical } \\
\text { portrayal in a way } \\
\text { that contributes to a } \\
\text { further or deeper } \\
\text { understanding. }\end{array}$ & $\begin{array}{l}\text { Competently converts } \\
\text { relevant information } \\
\text { into an appropriate } \\
\text { and desired } \\
\text { mathematical } \\
\text { portrayal. }\end{array}$ & $\begin{array}{l}\text { Completes } \\
\text { conversion of } \\
\text { information but } \\
\text { resulting } \\
\text { mathematical } \\
\text { portrayal is only } \\
\text { partially } \\
\text { appropriate or } \\
\text { accurate. }\end{array}$ & $\begin{array}{l}\text { Completes } \\
\text { conversion of } \\
\text { information but } \\
\text { resulting } \\
\text { mathematical } \\
\text { portrayal is } \\
\text { inappropriate or } \\
\text { inaccurate. }\end{array}$ \\
\hline Calculation & $\begin{array}{l}\text { Calculations } \\
\text { attempted are } \\
\text { essentially all } \\
\text { Successful and } \\
\text { sufficiently } \\
\text { comprehensive to } \\
\text { solve the problem. } \\
\text { Calculations are also } \\
\text { presented elegantly } \\
\text { (clearly, concisely, } \\
\text { etc.) }\end{array}$ & $\begin{array}{l}\text { Calculations } \\
\text { attempted are } \\
\text { essentially all } \\
\text { successful and } \\
\text { sufficiently } \\
\text { comprehensive to } \\
\text { solve the problem. }\end{array}$ & $\begin{array}{l}\text { Calculations } \\
\text { attempted are } \\
\text { either unsuccessful } \\
\text { or represent only a } \\
\text { portion of the } \\
\text { calculations } \\
\text { required to } \\
\text { comprehensively } \\
\text { solve the problem. }\end{array}$ & $\begin{array}{l}\text { Calculations are } \\
\text { attempted but are } \\
\text { both unsuccessful } \\
\text { and are not } \\
\text { comprehensive. }\end{array}$ \\
\hline $\begin{array}{l}\text { Application / } \\
\text { Analysis - } \\
\text { Ability to make } \\
\text { judgments and } \\
\text { draw appropriate } \\
\text { conclusions } \\
\text { based on the } \\
\text { quantitative } \\
\text { analysis of data, } \\
\text { while } \\
\text { recognizing the } \\
\text { limits of this } \\
\text { analysis }\end{array}$ & $\begin{array}{l}\text { Uses the quantitative } \\
\text { analysis of data as the } \\
\text { basis for deep and } \\
\text { thoughtful } \\
\text { judgments, drawing } \\
\text { insightful, carefully } \\
\text { qualified conclusions } \\
\text { from this work. }\end{array}$ & $\begin{array}{l}\text { Uses the quantitative } \\
\text { analysis of data as the } \\
\text { basis for competent } \\
\text { judgments, drawing } \\
\text { reasonable } \\
\text { and appropriately } \\
\text { qualified conclusions } \\
\text { from this work. }\end{array}$ & $\begin{array}{l}\text { Uses the } \\
\text { quantitative } \\
\text { analysis of data as } \\
\text { the basis for } \\
\text { workmanlike } \\
\text { (without inspiration } \\
\text { or nuance, } \\
\text { ordinary) } \\
\text { judgments, } \\
\text { drawing plausible } \\
\text { conclusions from } \\
\text { this work. }\end{array}$ & $\begin{array}{l}\text { Uses the quantitative } \\
\text { analysis of data as the } \\
\text { basis for tentative, } \\
\text { basic judgments, } \\
\text { although is hesitant } \\
\text { or uncertain about } \\
\text { drawing conclusions } \\
\text { from this work. }\end{array}$ \\
\hline
\end{tabular}

Student Outcome c. conduct standard tests and measurements; to conduct, analyze, and interpret experiments; and to apply experimental results to improve processes

There are three rubrics which can be used to measure various aspects of this student outcome. The first one, Problem Solving, can be used in its entirety. Below are the criteria, for performance descriptions, please view the complete set of rubrics.

\section{Problem Solving VALUE Rubric Criteria:}

- Define Problem

- Identify Strategies

- Propose Solutions/Hypotheses

- Evaluate Potential Solutions

- Implement Solution

- Evaluate Outcomes 
The second rubric used for outcome $\mathrm{c}$ is the Inquiry and Analysis VALUE Rubric. There are three criteria in this rubric that can be applied; Table 14 shows the relevant parts.

Table 14: Excerpt from "Inquiry and Analysis VALUE Rubric"

\begin{tabular}{|c|c|c|c|c|}
\hline & Capstone & \multicolumn{2}{|c|}{ Milestones } & Benchmark \\
\hline & 4 & 3 & 2 & 1 \\
\hline Analysis & $\begin{array}{l}\text { Organizes and } \\
\text { synthesizes evidence } \\
\text { to reveal insightful } \\
\text { patterns, differences, } \\
\text { or similarities related } \\
\text { to focus. }\end{array}$ & $\begin{array}{l}\text { Organizes evidence } \\
\text { to reveal important } \\
\text { patterns, differences, } \\
\text { or similarities related } \\
\text { to focus. }\end{array}$ & $\begin{array}{l}\text { Organizes } \\
\text { evidence, but the } \\
\text { organization is not } \\
\text { effective in } \\
\text { revealing important } \\
\text { patterns, } \\
\text { differences, or } \\
\text { similarities. }\end{array}$ & $\begin{array}{l}\text { Lists evidence, but it } \\
\text { is not organized and/ } \\
\text { or is unrelated to } \\
\text { focus. }\end{array}$ \\
\hline Conclusions & $\begin{array}{l}\text { States a conclusion } \\
\text { that is a logical } \\
\text { extrapolation from } \\
\text { the inquiry findings. }\end{array}$ & $\begin{array}{l}\text { States a conclusion } \\
\text { focused solely on the } \\
\text { inquiry findings. The } \\
\text { conclusion arises } \\
\text { specifically from and } \\
\text { responds specifically } \\
\text { to the inquiry } \\
\text { findings. }\end{array}$ & $\begin{array}{l}\text { States a general } \\
\text { conclusion that, } \\
\text { because it is so } \\
\text { general, also } \\
\text { applies beyond the } \\
\text { scope of the } \\
\text { inquiry findings. }\end{array}$ & $\begin{array}{l}\text { States an ambiguous, } \\
\text { illogical, or } \\
\text { unsupportable } \\
\text { conclusion from } \\
\text { inquiry findings. }\end{array}$ \\
\hline $\begin{array}{l}\text { Limitations and } \\
\text { Implications }\end{array}$ & $\begin{array}{l}\text { Insightfully discusses } \\
\text { in detail relevant and } \\
\text { supported limitations } \\
\text { and implications. }\end{array}$ & $\begin{array}{l}\text { Discusses relevant } \\
\text { and supported } \\
\text { limitations and } \\
\text { implications. }\end{array}$ & $\begin{array}{l}\text { Presents relevant } \\
\text { and supported } \\
\text { limitations and } \\
\text { implications. }\end{array}$ & $\begin{array}{l}\text { Presents limitations } \\
\text { and implications, but } \\
\text { they are possibly } \\
\text { irrelevant and } \\
\text { unsupported. }\end{array}$ \\
\hline
\end{tabular}

The third rubric, Integrative Learning, has one criterion that can be used for this outcome which is shown in Table 15.

Table 15: Excerpt from "Integrative Learning VALUE Rubric"

\begin{tabular}{|c|c|c|c|c|}
\hline $\begin{array}{l}\text { Transfer - } \\
\text { Adapts and } \\
\text { applies skills, } \\
\text { abilities, } \\
\text { theories, or } \\
\text { methodologies } \\
\text { gained in one } \\
\text { situation to new } \\
\text { situations }\end{array}$ & $\begin{array}{l}\text { Adapts and applies, } \\
\text { independently, skills, } \\
\text { abilities, theories, or } \\
\text { methodologies gained } \\
\text { in one situation to } \\
\text { new situations to } \\
\text { solve difficult } \\
\text { problems or explore } \\
\text { complex issues in } \\
\text { original ways. }\end{array}$ & $\begin{array}{l}\text { Adapts and applies } \\
\text { skills, abilities, } \\
\text { theories, or } \\
\text { methodologies gained } \\
\text { in one situation to } \\
\text { new situations to } \\
\text { solve problems or } \\
\text { explore issues. }\end{array}$ & $\begin{array}{l}\text { Uses skills, } \\
\text { abilities, theories, } \\
\text { or methodologies } \\
\text { gained in one } \\
\text { situation in a new } \\
\text { situation to } \\
\text { contribute to } \\
\text { understanding of } \\
\text { problems or issues. }\end{array}$ & $\begin{array}{l}\text { Uses, in a basic way, } \\
\text { skills, abilities, } \\
\text { theories, or } \\
\text { methodologies gained } \\
\text { in one situation in a } \\
\text { new situation. }\end{array}$ \\
\hline
\end{tabular}

Student Outcome d. design systems, components, or processes for broadly-defined engineering technology problems appropriate to program educational objectives

There are two rubrics which can be used to measure various aspects of this student outcome. The first one, Creative Thinking, has three criterions that apply. Table 16 shows excerpts from the VALUE rubric. 
Table 16: Excerpt from "Creative Thinking VALUE Rubric"

\begin{tabular}{|c|c|c|c|c|}
\hline $\begin{array}{l}\text { Solving } \\
\text { Problems }\end{array}$ & $\begin{array}{l}\text { Not only develops a } \\
\text { logical, consistent } \\
\text { plan to solve } \\
\text { problem, but } \\
\text { recognizes } \\
\text { consequences of } \\
\text { solution and can } \\
\text { articulate reason for } \\
\text { choosing solution. } \\
\end{array}$ & $\begin{array}{l}\text { Having selected from } \\
\text { among alternatives, } \\
\text { develops a logical, } \\
\text { consistent plan to } \\
\text { solve the problem. }\end{array}$ & $\begin{array}{l}\text { Considers and } \\
\text { rejects less } \\
\text { acceptable } \\
\text { approaches to } \\
\text { solving problem. }\end{array}$ & $\begin{array}{l}\text { Only a single } \\
\text { approach is } \\
\text { considered and is } \\
\text { used to solve the } \\
\text { problem. }\end{array}$ \\
\hline $\begin{array}{l}\text { Innovative } \\
\text { Thinking } \\
\text { Novelty or } \\
\text { uniqueness (of } \\
\text { idea, claim, } \\
\text { question, form, } \\
\text { etc.) }\end{array}$ & $\begin{array}{l}\text { Extends a novel or } \\
\text { unique idea, question, } \\
\text { format, or product to } \\
\text { create new } \\
\text { knowledge or } \\
\text { knowledge that } \\
\text { crosses boundaries. }\end{array}$ & $\begin{array}{l}\text { Creates a novel or } \\
\text { unique idea, question, } \\
\text { format, or product. }\end{array}$ & $\begin{array}{l}\text { Experiments with } \\
\text { creating a novel or } \\
\text { unique idea, } \\
\text { question, format, or } \\
\text { product. }\end{array}$ & $\begin{array}{l}\text { Reformulates a } \\
\text { collection of } \\
\text { available ideas. }\end{array}$ \\
\hline $\begin{array}{l}\text { Connecting, } \\
\text { Synthesizing, } \\
\text { Transforming }\end{array}$ & $\begin{array}{l}\text { Transforms ideas or } \\
\text { solutions into entirely } \\
\text { new forms. }\end{array}$ & $\begin{array}{l}\text { Synthesizes ideas or } \\
\text { solutions into a } \\
\text { coherent whole. }\end{array}$ & $\begin{array}{l}\text { Connects ideas or } \\
\text { solutions in novel } \\
\text { ways. }\end{array}$ & $\begin{array}{l}\text { Recognizes existing } \\
\text { connections among } \\
\text { ideas or solutions. }\end{array}$ \\
\hline
\end{tabular}

The second Rubric that applies is the Problem Solving Rubric. Two of the criteria apply here. Below are excerpts from the VALUE rubric.

Table 17: Excerpt from "Problem Solving VALUE Rubric"

\begin{tabular}{|c|c|c|c|c|}
\hline $\begin{array}{l}\text { Propose } \\
\text { Solutions/ } \\
\text { Hypotheses }\end{array}$ & $\begin{array}{l}\text { Proposes one or more } \\
\text { solutions/ hypotheses } \\
\text { that indicates a deep } \\
\text { comprehension of the } \\
\text { problem. Solution/ } \\
\text { hypotheses are } \\
\text { sensitive to } \\
\text { contextual factors as } \\
\text { well as all of the } \\
\text { following: ethical, } \\
\text { logical, and cultural } \\
\text { dimensions of the } \\
\text { problem. }\end{array}$ & $\begin{array}{l}\text { Proposes one or more } \\
\text { solutions/ hypotheses } \\
\text { that indicates } \\
\text { comprehension of the } \\
\text { problem. Solutions/ } \\
\text { hypotheses are } \\
\text { sensitive to } \\
\text { contextual factors as } \\
\text { well as the one of the } \\
\text { following: ethical, } \\
\text { logical, or cultural } \\
\text { dimensions of the } \\
\text { problem. }\end{array}$ & $\begin{array}{l}\text { Proposes one } \\
\text { solution/ } \\
\text { hypothesis that is } \\
\text { "off the shelf” } \\
\text { rather than } \\
\text { individually } \\
\text { designed to address } \\
\text { the specific } \\
\text { contextual factors } \\
\text { of the problem. }\end{array}$ & $\begin{array}{l}\text { Proposes a solution/ } \\
\text { hypothesis that is } \\
\text { difficult to evaluate } \\
\text { because it is vague or } \\
\text { only indirectly } \\
\text { addresses the } \\
\text { problem statement. }\end{array}$ \\
\hline $\begin{array}{l}\text { Evaluate } \\
\text { Potential } \\
\text { Solutions }\end{array}$ & $\begin{array}{l}\text { Evaluation of } \\
\text { solutions is deep and } \\
\text { elegant (for example, } \\
\text { contains thorough } \\
\text { and insightful } \\
\text { explanation) and } \\
\text { includes, deeply and } \\
\text { thoroughly, all of the } \\
\text { following: considers } \\
\text { history of problem, } \\
\text { reviews logic/ } \\
\text { reasoning, examines } \\
\text { feasibility of solution, } \\
\text { and weighs impacts } \\
\text { of solution. }\end{array}$ & $\begin{array}{l}\text { Evaluation of } \\
\text { solutions is adequate } \\
\text { (for example, } \\
\text { contains thorough } \\
\text { explanation) } \\
\text { and includes the } \\
\text { following: considers } \\
\text { history of problem, } \\
\text { reviews logic/ } \\
\text { reasoning, examines } \\
\text { feasibility of solution, } \\
\text { and weighs impacts } \\
\text { of solution. }\end{array}$ & $\begin{array}{l}\text { Evaluation of } \\
\text { solutions is brief } \\
\text { (for example, } \\
\text { explanation lacks } \\
\text { depth) and includes } \\
\text { the following: } \\
\text { considers history of } \\
\text { problem, reviews } \\
\text { logic/ reasoning, } \\
\text { examines } \\
\text { feasibility of } \\
\text { solution, and } \\
\text { weighs impacts of } \\
\text { solution. }\end{array}$ & $\begin{array}{l}\text { Evaluation of } \\
\text { solutions is } \\
\text { superficial (for } \\
\text { example, contains } \\
\text { cursory, surface level } \\
\text { explanation) and } \\
\text { includes the } \\
\text { following: considers } \\
\text { history of problem, } \\
\text { reviews logic/ } \\
\text { reasoning, examines } \\
\text { feasibility of solution, } \\
\text { and weighs impacts } \\
\text { of solution. }\end{array}$ \\
\hline
\end{tabular}


Student Outcome f. an ability to identify, analyze, and solve broadly-defined engineering technology problems;

Problem solving is a complex skill, and several of the VALUE rubrics can contribute to its measurement. The Problem Solving VALUE rubric is an obvious choice. The criteria are:

- Define Problem

- Identify Strategies

- Propose Solutions/ Hypotheses

- Evaluate Potential Solutions

- Implement Solution

- Evaluate Outcomes

The Creative Thinking Rubric is another one that can be used in its entirety for problem solving skills. The criteria for this rubric are:

- Acquiring Competencies

- Taking Risks

- Solving Problems

- Embracing Contradictions

- Innovative Thinking

- Connecting, Synthesizing, Transforming

For the performance descriptions of the Critical Thinking rubric, please see the complete set of rubrics.

In addition to the Problem Solving and Creative Thinking rubrics, there are two criteria from the Inquiry and Analysis Rubric that apply to this outcome. Below are excerpts from the VALUE rubric.

Table 18: Excerpt from "Inquiry and Analysis VALUE Rubric"

\begin{tabular}{|l|l|l|l|l|}
\hline Design Process & $\begin{array}{l}\text { All elements of the } \\
\text { methodology or } \\
\text { theoretical framework } \\
\text { are skillfully } \\
\text { developed. } \\
\text { Appropriate } \\
\text { methodology or } \\
\text { theoretical frameworks } \\
\text { may be synthesized } \\
\text { from across disciplines } \\
\text { or from relevant sub- } \\
\text { disciplines. }\end{array}$ & $\begin{array}{l}\text { Critical elements of } \\
\text { the methodology or } \\
\text { theoretical framework } \\
\text { are appropriately } \\
\text { developed, however, } \\
\text { more subtle elements } \\
\text { are ignored or } \\
\text { unaccounted for. }\end{array}$ & $\begin{array}{l}\text { Critical elements of } \\
\text { the methodology or } \\
\text { theoretical } \\
\text { framework are } \\
\text { missing, incorrectly } \\
\text { developed, or } \\
\text { unfocused. }\end{array}$ & $\begin{array}{l}\text { Inquiry design } \\
\text { demstrates a } \\
\text { misunderstanding of } \\
\text { the methodology or } \\
\text { theoretical framework. }\end{array}$ \\
\hline Analysis & $\begin{array}{l}\text { Organizes and } \\
\text { synthesizes evidence to } \\
\text { reveal insightful } \\
\text { patterns, differences, or } \\
\text { similarities related to } \\
\text { focus. }\end{array}$ & $\begin{array}{l}\text { Organizes evidence to } \\
\text { reveal important } \\
\text { patterns, differences, or } \\
\text { similarities related to } \\
\text { focus. }\end{array}$ & $\begin{array}{l}\text { Organizes evidence, } \\
\text { but the organization } \\
\text { is not effective in } \\
\text { revealing important } \\
\text { patterns, } \\
\text { differences, or } \\
\text { similarities. }\end{array}$ & $\begin{array}{l}\text { Lists evidence, but it is } \\
\text { not organized and/or is } \\
\text { unrelated to focus. }\end{array}$ \\
\hline
\end{tabular}


The last rubric that applies to this outcome is the Quantitative Literacy Rubric. The one criterion that applies can be viewed in Table 19.

Table 19: Excerpt from "Quantitative Literacy VALUE Rubric"

\begin{tabular}{|c|c|c|c|c|}
\hline $\begin{array}{l}\text { Application / } \\
\text { Analysis - } \\
\text { Ability to make } \\
\text { judgments and } \\
\text { draw } \\
\text { appropriate } \\
\text { conclusions } \\
\text { based on the } \\
\text { quantitative } \\
\text { analysis of data, } \\
\text { while } \\
\text { recognizing the } \\
\text { limits of this } \\
\text { analysis }\end{array}$ & $\begin{array}{l}\text { Uses the quantitative } \\
\text { analysis of data as } \\
\text { the basis for deep and } \\
\text { thoughtful judgments, } \\
\text { drawing insightful, } \\
\text { carefully qualified } \\
\text { conclusions from this } \\
\text { work. }\end{array}$ & $\begin{array}{l}\text { Uses the quantitative } \\
\text { analysis of data as } \\
\text { the basis for } \\
\text { competent } \\
\text { judgments, drawing } \\
\text { reasonable and } \\
\text { appropriately } \\
\text { qualified } \\
\text { conclusions from } \\
\text { this work. }\end{array}$ & $\begin{array}{l}\text { Uses the } \\
\text { quantitative } \\
\text { analysis of data as } \\
\text { the basis for } \\
\text { workmanlike } \\
\text { (without inspiration } \\
\text { or nuance, } \\
\text { ordinary) } \\
\text { judgments, drawing } \\
\text { plausible } \\
\text { conclusions from } \\
\text { this work. }\end{array}$ & $\begin{array}{l}\text { Uses the quantitative } \\
\text { analysis of data as } \\
\text { the basis for tentative, } \\
\text { basic judgments, } \\
\text { although is hesitant or } \\
\text { uncertain about } \\
\text { drawing conclusions } \\
\text { from this work. }\end{array}$ \\
\hline
\end{tabular}

\section{Implementation}

All the VALUE rubrics have descriptions and suggestions for use. Through implementation of these rubrics, we are able to collect data on the achievement of outcomes. Once criteria are selected they can be applied specifically to student work. Typically, the rubrics will be applied to a course assignment, such as a particular activity, report, or presentation. They can also be used to assess a co-curricular experience, such as an internship or competition.

By using a rubric with clear performance descriptions, inter-rater reliability is improved and faculty will more accurately track improvement in student achievement which might be credited to changes in the program rather than changes in rater opinion. For example, an instructor may observe weak teamwork skills in a class one semester, and change the training students receive in conflict resolution the following semester. The instructor monitors the results using the teamwork rubric. If student performance improves, it is likely due to the change of training. Of course, improvement might be due to other factors, but by using a rubric, we lessen the chance that the improvement is due to instructor attitudes.

Twelve case studies have been conducted and are presented on the ACC\&U website. The vast majority of applications are in general education. However, the College of Business of Lewis University reports using the Critical Thinking Rubric in their economics courses. Business faculty scored embedded assignments to assess student learning ${ }^{4}$. Other case studies describe how the VALUE rubrics were adapted to local needs.

\section{Conclusion}

The VALUE Rubrics provide a valuable resource to assess student achievement associated with general education. Several of the rubrics may be applied in whole or in part to assess student outcomes as required for ABET accreditation. The VALUE rubrics are well suited to assess professionalism skills, such as communication and societal context and some technical skills such as problem solving. They can also serve as a starting point to create new rubrics to assess other skills. 


\section{Bibliography}

1. Spurlin, Joni E. (2008). Assessment Methods Used in Undergraduate Program Assessment. In J. E. Spurlin et al (Eds.), Designing Better Engineering Education Through Assessment (p 68). Sterling, Virginia: Stylus.

2. Association of American Colleges and Universities. (2013). VALUE: Valid Assessment of Learning in Undergraduate Education. Retrieved from http://www.aacu.org/value/project_description.cfm

3. ABET Engineering Technology Accreditation Commission. (2013). 2014-2015 Criteria for Accrediting Engineering Technology Programs,. Retrieved from

http://www.abet.org/uploadedFiles/Accreditation/Accreditation_Step_by_Step/Accreditation_Documents/C urrent/2014 - 2015/T001\%2014-15\%20ETAC\%20Criteria\%2010-26-13.pdf

4. Klemic, George G. (2011). Use of the VALUE Rubrics in the College of Business of Lewis University. Retrieved from http://www.aacu.org/value/casestudies/lewis.pdf 


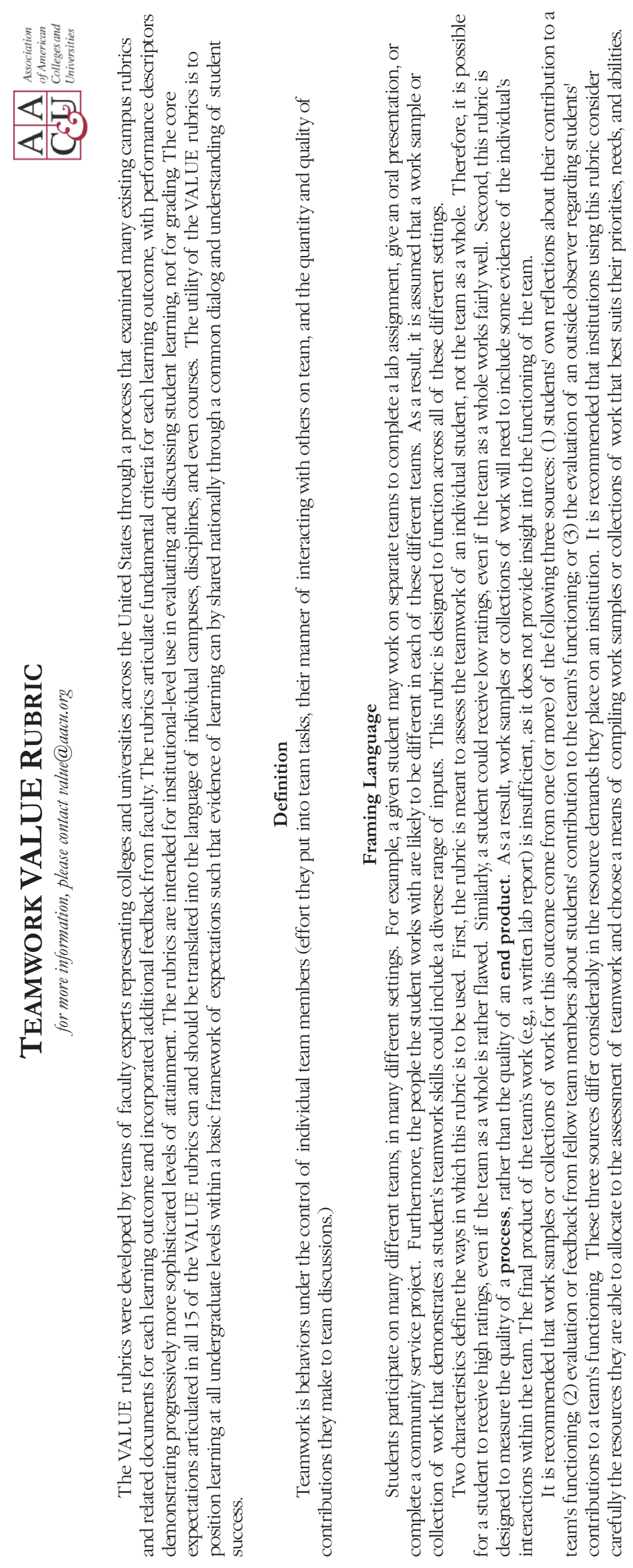



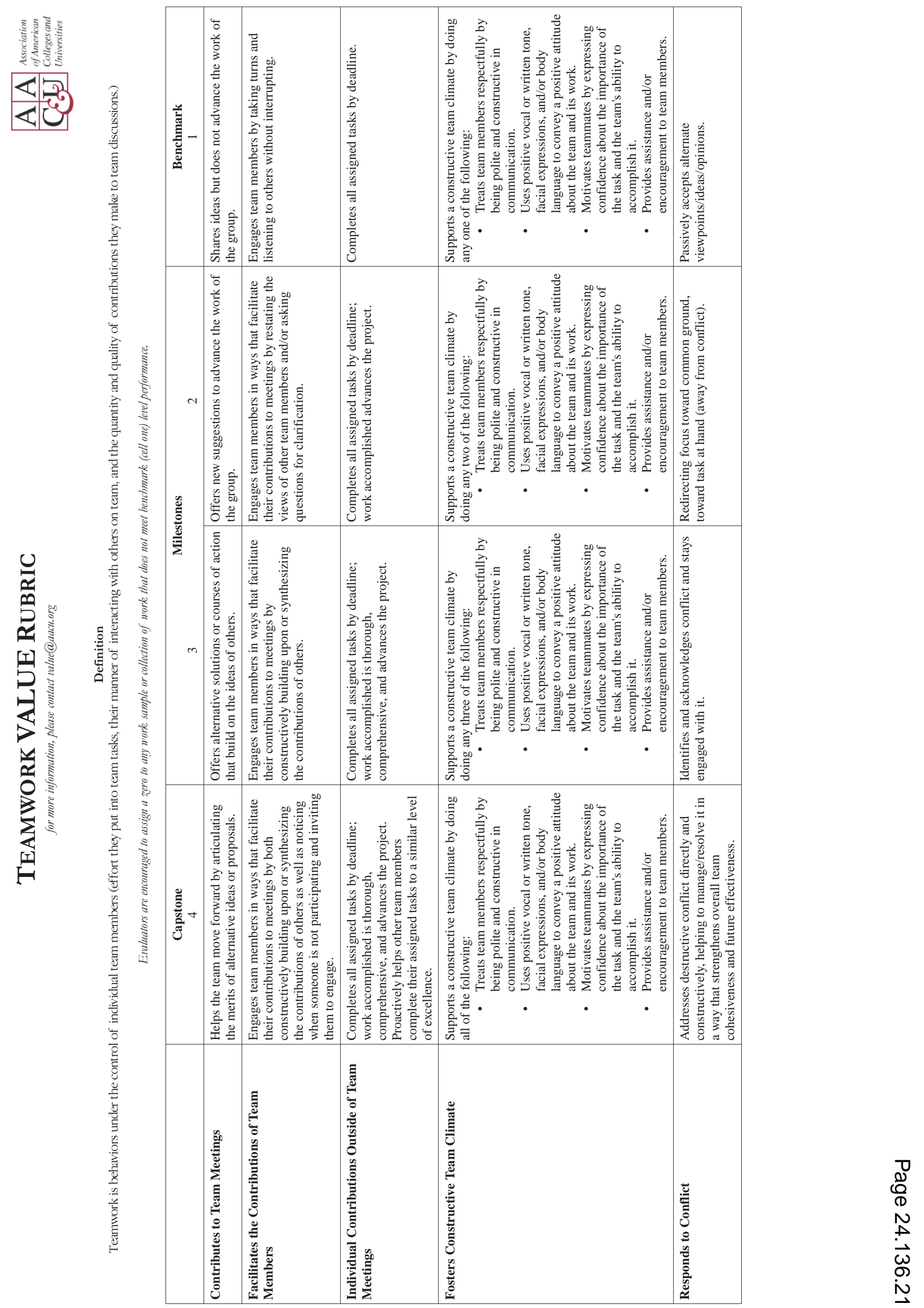